\title{
Diaporthe nebulae sp. nov. and First Report of D. cynaroidis, D. novem, and $D$. serafiniae on Grapevines in South Africa
}

\author{
Palesa Lesuthu, ${ }^{1,3}$ Lizel Mostert, ${ }^{2}$ Christoffel F. J. Spies, ${ }^{1,2}$ Providence Moyo, ${ }^{2}$ Thierry Regnier, ${ }^{3}$ and Francois Halleen ${ }^{1,2, \dagger}$ \\ ${ }^{1}$ Plant Protection Division, ARC Infruitec-Nietvoorbij, Private Bag X5026, Stellenbosch, 7599, South Africa; ${ }^{2}$ Department of \\ Plant Pathology, University of Stellenbosch, Private Bag X1, Matieland, 7602, South Africa; and ${ }^{3}$ Department of Biotechnology \\ and Food Technology, Tshwane University of Technology, Private Bag X680, Pretoria, 0001, South Africa
}

\begin{abstract}
Diaporthe species cause Phomopsis cane and leaf spot as well as Phomopsis dieback on grapevines. Symptoms of Phomopsis dieback have increasingly been observed over the past few years. In order to assess the current status of Diaporthe on grapevines in the Western Cape Province of South Africa, isolations were made from dormant grafted nursery vines, dormant rootstock canes, and dying or dead spurs of field vines. Cultures identified as Diaporthe based on morphological features were further identified to species level by sequencing the internal transcribed spacers (ITS) 1 and 2 and 5.8S rRNA and, for a representative subsample of isolates, the partial beta-tubulin (tub2) and translation elongation

factor 1-alpha (EF1- $\alpha)$ genes. Phylogenetic analysis of the combined ITS, tub2, and EF1- $\alpha$ data revealed nine Diaporthe species associated with grapevines during this survey. One of these represents a new species, D. nebulae sp. nov., and three other species, namely $D$. novem, $D$. cynaroidis, and D. serafiniae, are reported on grapevines in South Africa for the first time. Species-specific primers were designed for PCR identification of $D$. ampelina, D. ambigua, and D. foeniculina. Pathogenicity studies conducted on detached grapevine shoots indicated $D$. ampelina, D. novem, and D. nebulae sp. nov. as the most virulent species.
\end{abstract}

Species of Diaporthe Nitschke are either endophytes, saprobes, or pathogens on a wide range of hosts, and are responsible for several plant diseases, including root and fruit rots, stem cankers, dieback, pod blights, seed decay, wilts, and leaf spots (Díaz et al. 2017; Dissanayake et al. 2015; Guarnaccia and Crous 2017; Guarnaccia et al. 2018; Mostert et al. 2001; Rehner and Uecker 1994; Udayanga et al. 2011). The recent abolishment of dual nomenclature in the International Code of Nomenclature for algae, fungi, and plants (ICN) has forced fungal taxonomy to move to a single nomenclature for fungi (Hawksworth 2011; Hawksworth et al. 2011). The generic names Diaporthe and Phomopsis are no longer used to distinguish different morphs of this genus, and a recent study by Rossman et al. (2015) has recommended that Diaporthe should be retained over Phomopsis because it was introduced first and represent the majority of species. Species recognition of Diaporthe have historically been defined based on host association and morphology (Uecker 1988). Recent studies have, however, shown that various species can be found on a single host and are able to infect a wide range of hosts (Baumgartner et al. 2013; Gomes et al. 2013; Guarnaccia and Crous 2017; Guarnaccia et al. 2016; Mostert et al. 2001; Rehner and Uecker 1994; Santos and Phillips 2009; Thompson et al. 2011, 2015; Van

${ }^{\dagger}$ Corresponding author: F. Halleen; E-mail: Halleenf@arc.agric.za

Funding: This research was funded by Winetech project P0400084. The authors also acknowledge the Agricultural Research Council (ARC) and Technology and Human Resources for Industry Programme (THRIP) for funding.

Current address of C. F. J. Spies: ARC-Plant Health and Protection, Private Bag X5017, Stellenbosch, 7599, South Africa.

Current address of P. Moyo: Citrus Research International, P.O. Box 28, Nelspruit, 1200, South Africa.

Accepted for publication 19 September 2018.

() 2019 The American Phytopathological Society
Niekerk et al. 2005). Therefore, identification and description of species based on host association and morphology is no longer reliable within the genus (Gomes et al. 2013; Udayanga et al. 2014a, b). Diaporthe species associated with grapevines are now studied worldwide using the combination of morphology, pathogenicity, and molecular data (Dissanayake et al. 2015; Guarnaccia et al. 2018; Mostert et al. 2001; Rehner and Uecker 1994; UrbezTorres et al. 2013; Van Niekerk et al. 2005). On this host, Diaporthe ampelina has been found to be the predominant and most virulent Diaporthe species in several grape-producing countries in the world (Baumgartner et al. 2013; Dissanayake et al. 2015; Guarnaccia et al. 2018; Mostert et al. 2001; Pscheidt and Pearson 1989; Rehner and Uecker 1994; Urbez-Torres et al. 2013; Van Niekerk et al. 2005). For many years, this pathogen was associated with 'dead-arm' disease until it was eventually discovered that Eutypa lata and not D. ampelina caused dead arm disease of grapevine (Berrysmith 1962; Moller and Kasimatis 1981; Pearson and Goheen 1994; UrbezTorres et al. 2013). However, Urbez-Torres et al. (2013) recently confirmed $D$. ampelina as grapevine canker causing agent, proposing the name Phomopsis dieback. In addition to Phomopsis dieback, D. ampelina is also the causal agent of Phomopsis cane and leaf spot, a disease that causes serious losses due to shoots breaking off at the base, dieback, loss of vigor, stunting, reduced bunch set, and fruit rot. Infected canes show brown to black necrosis with oval shaped lesions on the first three to six basal internodes. Clusters may develop rachis necrosis, which results in brown, shriveled berries close to harvest. Leaf symptoms include small, pale green to yellow spots with necrotic centers (Guarnaccia et al. 2018; Pearson and Goheen 1994; Urbez-Torres et al. 2013; Wilcox et al. 2015). Halleen et al. (2003) and Fourie and Halleen (2004a) reported D. ampelina to occur and invade rootstock mother plants, propagation material, and grafted vines in South African nursery fields. A total yield loss of between 20 and $30 \%$ has been reported as a result of infection by this fungus on grapevines (Pscheidt and Pearson 1989; Urbez-Torres et al. 2013).

In South Africa, Phomopsis cane and leaf spot was first noticed in 1935 (Du Plessis 1938), and Diaporthe species have since then also 
been acknowledged as grapevine trunk disease pathogens causing cankers and dieback on vines (Mostert et al. 2001; Van Niekerk et al. 2005; White et al. 2011a, b). Mostert et al. (2001) found 10 Diaporthe spp. to occur on South African grapevines, and of these, $D$. ampelina, D. kyushuensis, D. amygdali, and D. australafricana are confirmed as being pathogenic to this host. In a later study, Van Niekerk et al. (2005) found 15 Diaporthe spp. occurring on grapevines in South Africa, with D. ampelina and D. amygdali being the most virulent. Moreover, eight distinct species of the 15 were unidentified (Phomopsis spp. 1-8). Phomopsis sp. 1 has since been identified as D. foeniculina (Santos and Phillips 2009) and Phomopsis sp. 6 as D. eres (Udayanga et al. 2014b), based on published phylogenies.

Correct identification of Diaporthe spp. is an essential step toward meaningful studies on epidemiology and disease management. The ITS region is often useful in the identification of Diaporthe spp., but the intraspecific variation observed in ITS sequences of several Diaporthe spp. can cause confusion in species recognition when used alone (Farr et al. 2017; Santos et al. 2010). Recent publications have advocated the use of beta-tubulin (tub2), calmodulin (CAL), histone H3 (HIS), internal transcribed spacers (ITS), and the translation elongation factor 1-alpha (EF1- $\alpha$ ) for phylogenetic analyses in Diaporthe (Guarnaccia and Crous 2017; Guarnaccia et al. 2018; Santos et al. 2017; Udayanga et al. 2012). Of these five regions, the EF1- $\alpha$ is considered to be most useful for species identification (Santos et al. 2017). Udayanga et al. (2014b) also made use of the actin region (ACT) to assist in the resolution of phylogenetic relationships in the D. eres species complex, but the usefulness of this region in resolving relationships among other species in the genus has not been determined.

Molecular identification assays have become very popular as fast and sensitive alternatives to conventional culture-based techniques for identifying plant pathogens in infected plant tissues. Specific PCR assays using genus-specific primers for Diaporthe such as Phf/Phr (Prasad et al. 2006) and PF1/PF2 (Girish et al. 2009) have been reported. Species-specific primers have been designed for the identification and detection of D. phaseolorum, D. longicolla, and D. azadirachtae (Vedashree et al. 2015; Zhang et al. 1997); however, species-specific primers to identify additional Diaporthe spp. on grapevines are lacking.

The total number of Diaporthe species on grapevines has been increasing worldwide ever since Mostert et al. (2001) and Van Niekerk et al. (2005) published their studies more than 10 years ago. This raised questions about the current status of Diaporthe spp. on grapevines in South Africa. During the past 3 years, unknown Diaporthe isolates were regularly recovered from grapevines in the Western Cape Province of South Africa. It was therefore necessary to reassess the status of Diaporthe species on South African grapevines. To this end, the aims of this study were to (i) identify Diaporthe spp. associated with grapevine dieback symptoms in the Western Cape Province, (ii) relocate unidentified isolates of Van Niekerk et al. (2005) to known species where possible, (iii) characterize species not previously reported on grapevines in South Africa in terms of pathogenicity and morphology, and (iv) develop species-specific PCR assays for the most common Diaporthe spp. identified.

\section{Materials and Methods}

Sample collection and fungal isolation. Dormant grafted nursery vines $(n=700)$ and dormant rootstock propagation material $(n=74)$ were collected from various viticultural regions of the Western Cape Province over a period of 3 years to obtain isolates of Diaporthe species. In addition, dying spurs $(n=360)$ were also collected from established vineyards in the different grapevine producing areas of the Western Cape Province, over a period of 2 years. Samples were cut into transverse and longitudinal sections to reveal internal symptoms such as black streaking, brown streaking, or V-shaped necrosis (White et al. 2011b). Cuttings were then surface sterilized and isolations were made onto potato dextrose agar (PDA, Biolab, South Africa) containing chloramphenicol (250 mg/liter), following the protocol described by Moyo et al. (2016). Plates were then incubated at $25^{\circ} \mathrm{C}$ and monitored every 1 to 3 days for a period of 4 weeks for growth of trunk disease pathogens. Throughout this 4-week period, subcultures of fungal growth resembling Diaporthe were cultured on fresh PDA plates in order to obtain pure cultures. All cultures were maintained as agar plugs in sterile water and stored at $4{ }^{\circ} \mathrm{C}$ at the Nietvoorbij campus of the Agricultural Research Council.

DNA extraction, PCR amplification, and sequencing. The isolation protocol described by Damm et al. (2008) was used to extract DNA from aerial mycelium of actively growing PDA cultures of Diaporthe-like isolates. The ITS region was amplified for all isolates and sequenced in one direction to facilitate preliminary species-level identifications. Based on these preliminary results, representative isolates were selected for sequencing of double-strand ITS, betatubulin (tub2), and EF1- $\alpha$ regions. ITS amplifications were performed using the universal fungal primers ITS1 and ITS4 (White et al. 1990). The partial tub2 region was amplified using the primers T1 (O’Donnell and Cigelnik 1997) and Bt2b (Glass and Donaldson 1995). The primers EF1-728F and EF2 (Carbone and Kohn 1999) were used to amplify part of the translation elongation factor 1-alpha (EF1- $\alpha$ ). The methods described by Moyo et al. (2016) for PCR amplification, purification, and sequencing of the PCR products was followed for ITS, $t u b 2$, and EF1- $\alpha$. Sequences obtained were evaluated, edited, and assembled (ITS, $t u b 2$, and $E F 1-\alpha$ for selected isolates only) using Geneious version R8.0.5 (https://www.geneious.com, Kearse et al. 2012).

Phylogenetic analysis. Initial species identification was done by using megablast searches of the GenBank nucleotide database (www.ncbi.nlm.nih.gov). ITS, tub2, and EF1- $\alpha$ reference sequences representing relevant Diaporthe species and Diaporthella corylina (CBS 121124) as outgroup were obtained from GenBank (Table 1). Diaporthe isolates obtained during this study were aligned with reference sequences in Geneious R8.0.5 using the L-INS-i algorithm of MAFFT V7. 017 (Katoh et al. 2009) and manually adjusted where necessary. Preliminary phylogenetic analysis with single strand ITS sequences of all the grapevine Diaporthe isolates containing the ITS reference sequences was conducted to identify representative strains for inclusion in the combined ITS-tub2-EF1- $\alpha$ phylogeny. ITS, tub2, and EF1- $\alpha$ alignments for the combined phylogeny were aligned separately as described above and concatenated in Geneious R8.0.5. Maximum likelihood phylogenetic analysis of the combined ITS-tub2-EF1- $\alpha$ dataset was performed using PhyML 3.1 (Guindon et al. 2010) under the HKY+I+G model, which was among the top two best models estimated in jModeltest2 (Darriba et al. 2012) using the Bayesian information criterion for each of the individual alignments (ITS, tub2, EF1- $\alpha$ ). Maximum likelihood bootstrap support was calculated from 1,000 replicates. Bayesian analyses were performed using PhyloBayes-MPI v. 1.7 (Lartillot et al. 2013) under CAT-GTR settings. Two independent chains were run for 4,800 cycles, of which every 10 th point was saved. Of the 480 saved points, the first 120 were discarded as burn-in prior to assessing convergence using the bpcomp and tracecomp commands. The effective population sizes after running these commands were larger than 250 and maxdiff values were less than 0.25 , indicating acceptable convergence as per the guidelines set out in the PhyloBayes-MPI manual. Trees were viewed and edited using Figtree 1.4.2 (http://tree. bio.ed.ac.uk/software/figtree/). Sequences obtained from GenBank are listed by their accession numbers, followed by taxon names (Fig. 1), while newly generated sequences are listed by their isolate numbers. Newly generated sequences have been deposited in GenBank (Table 1), alignments and phylogenies in TreeBASE (Submission number: 20684).

Morphological characterization. To determine morphological characteristics of new Diaporthe species, isolates were plated onto three different types of media: PDA, malt extract agar (MEA), and water agar (WA) containing 4-cm-long pieces of double autoclaved pine needles or grapevine shoots to induce sporulation. The plates were then incubated at $25^{\circ} \mathrm{C}$ near ultraviolet light in a 12-h lightdarkness regime for 4 weeks to induce sporulation. When fruiting structures were observed, they were mounted in $70 \%$ lactic acid onto a microscope slide and observed under 1,000 $\times$ magnification. The size, shape, and type of conidia were recorded. Thirty spore measurements were taken for each isolate (length and width), the minimum 
and maximum ranges of spore dimensions were recorded, and the averages determined.

Pathogenicity. Four Diaporthe species, namely: D. novem, $D$. serafiniae, D. cynaroidis, and a new species (D. nebulae) were selected to evaluate their potential as pathogens of grapevines since they were identified for the first time on South African grapevines. D. ampelina was used as a positive control since it is known to be highly virulent, and PDA media were used as negative control. Three different isolates per species were selected for the five Diaporthe species, plated out onto PDA media, and incubated at $25^{\circ} \mathrm{C}$ for 4 weeks.
One hundred and eighty dormant pruned shoots were collected from a 4-year-old Bukettraube (Vitis vinifera) vineyard at the Nietvoorbij campus of the Agricultural Research Council and subjected to hot water treatment following the protocol of Fourie and Halleen (2004b). This treatment significantly reduced the incidence of latent pathogen infections as well as any superficial pathogens that may be present on the canes. After this treatment, shoots were wounded between two nodes ( $2 \mathrm{~mm}$ deep) using a 3-mm cork-borer. Plugs were made from the outer margin of colonized agar of the five Diaporthe spp. including the positive control, and uncolonized agar (negative

Table 1. List of Diaporthe isolates collected in this study and reference strains (from GenBank) studied and included in the phylogenetic analysis

\begin{tabular}{|c|c|c|c|c|c|}
\hline Species & Strain/ isolate & Host & ITS accession & $t u b 2$ accession & EF1- $\alpha$ accession \\
\hline Diaporthella corylina & CBS 121124 & Corylus sp. & KC343004 & KC343972 & KC343730 \\
\hline Diaporthe alleghaniensis & CBS 495.72 & Betulaceae & KC343007 & KC343975 & KC343733 \\
\hline D. alnea & CBS 146.46 & Betulaceae & KC343008 & KC343976 & KC34373 \\
\hline D. ambigua & CBS 187.87 & Helianthus annuus & KC343015 & KC343983 & KC343741 \\
\hline D. ambigua & CBS 114015 & Pyrus communis & KC343010 & KC343978 & KC343736 \\
\hline D. ambigua & Phom 207 & US 8-7 & KY511309 & - & - \\
\hline D. ambigua & PMM 1734 & Vitis vinifera & KY511339 & KY511371 & - \\
\hline D. ampelina & CBS 111888 & Vitis vinifera & KC343016 & KC343984 & KC343742 \\
\hline D. ampelina & CBS 114867 & Vitis vinifera & KC343017 & KC343985 & KC343743 \\
\hline D. ampelina & Phom 206 & Vitis sp. (rootstock) & KY511308 & KY511341 & MH708549 \\
\hline D. ampelina & Phom 209 & Vitis sp. (rootstock) & KY511310 & KY511342 & MH708548 \\
\hline D. ampelina & Phom 214 & Vitis sp. (rootstock) & KY511311 & KY511343 & MH708547 \\
\hline D. ampelina & Phom 275 & Vitis champinii & KY511319 & KY511353 & - \\
\hline D. ampelina & Phom 281 & Vitis sp. (rootstock) & KY511322 & KY511354 & MH708542 \\
\hline D. amygdali & CBS 126679 & Prunus dulcis & KC343022 & KC343990 & KC343748 \\
\hline D. anacardii & CBS 720.97 & Anacardium occidentale & KC343024 & KC343992 & KC343750 \\
\hline D. arecae & CBS 535.75 & Citrus sp. & KC343033 & KC344001 & KC343759 \\
\hline D. australafricana & CBS 111886 & Vitis vinifera & KC343038 & KC344005 & KC343764 \\
\hline D. beckhausii & CBS 138.27 & Vibumum sp. & KC343041 & KC344009 & KC343767 \\
\hline D. bicincta & CBS 121004 & Juglans sp. & KC343618 & KC344102 & KC343860 \\
\hline D. casstaneae-mollissimae & DNP 128 & Lithocarpus glabra & JF957786 & JX275438 & JX275401 \\
\hline D. chamaeropis & CBS 753.70 & Spartium junceum & KC343049 & KC344017 & KC343775 \\
\hline D. cinerascens & CBS 719.96 & Ficus carica & KC343050 & KC344018 & KC343776 \\
\hline D. citri & AR 3405 & Citrus sp. & KC843311 & KC843187 & KC843071 \\
\hline D. citrichinensis & ZJUD 34 & Citrus sinensis & JQ954648 & KC357459 & JQ954648 \\
\hline D. cuppatea & CBS 117499 & Aspalathus linearis & KC343057 & KC344025 & KC343783 \\
\hline D. cynaroidis & CBS 122676 & Protea cynaroides & KC343058 & KC344026 & KC343784 \\
\hline D. cynaroidis & PMM 436 & Vitis vinifera & KY511326 & KY511358 & MH708541 \\
\hline D. cynaroidis & PMM 437 & Vitis vinifera & KY511327 & KY511359 & - \\
\hline D. cynaroidis & PMM 1658 & Vitis vinifera & KY511332 & KY511364 & - \\
\hline D. cytosporella & AR 5148 & Citrus sinensis & KC843309 & KC843223 & KC843118 \\
\hline D. endophytica & CBS 133811 & Schinus terebinthifolius & KC343065 & KC344033 & KC343791 \\
\hline D. eres & CBS 101742 & Fraxinus sp. & KC343073 & KC344041 & KC343799 \\
\hline D. eres & PMM 1690 & Vitis vinifera & KY511338 & KY511370 & - \\
\hline D. eres & AR 5193 & Ulmus laevis & KJ210529 & KJ420799 & KJ210550 \\
\hline D. eres & AR 5196 & Ulmus laevis & KJ210533 & KJ420817 & KJ210554 \\
\hline D. eres & AR 5223 & Acer nugundo & KJ210528 & KJ420830 & KJ210549 \\
\hline D. eres & CBS 109767 & Acer sp. & DQ491514 & KC344043 & KC343801 \\
\hline D. eres & CBS 439.82 & Cotoneaster sp. & FJ889450 & JX275437 & KC343816 \\
\hline D. eres & DP 0667 & Juglandaceae & KC843328 & KC843229 & KC843121 \\
\hline D. eres & LCM $114.01_{\mathrm{a}}$ & Ulmus sp. & KJ210521 & KJ420787 & KJ210545 \\
\hline D. eres & DLR $12_{\mathrm{a}}$ & Vitis vinifera & KJ210518 & KJ420783 & KJ210542 \\
\hline D. eugeniae & CBS 444.82 & Eugenia aromatica & KC343098 & KC344066 & KC343824 \\
\hline D. fibrosa & CBS 113830 & Rhamnus cathartica & KC343100 & KC344068 & KC343825 \\
\hline D. foeniculina & CBS 116957 & Pyrus pyrifolia & KC343103 & KC344071 & KC343829 \\
\hline D. foeniculina & CBS 123209 & Foeniculum vulgare & KC343105 & KC344073 & KC343831 \\
\hline D. foeniculina & Phom 224 & Vitis champinii & KY511312 & - & MH708546 \\
\hline D. foeniculina & PMM 463 & Vitis vinifera & KY511328 & KY511352 & - \\
\hline D. foeniculina & PMM 480 & Vitis vinifera & KY511329 & - & MH708540 \\
\hline D. foeniculina & PMM 1638 & Vitis vinifera & KY511330 & KY511362 & MH708551 \\
\hline D. foeniculina & PMM 1679 & Vitis vinifera & KY511335 & KY511367 & - \\
\hline D. foeniculina & PMM 1680 & Vitis vinifera & KY511336 & KY511368 & MH708539 \\
\hline D. fusicola & CGMCC3.17087 & Lithocarpus glabra & KF576281 & KF576305 & KF576256 \\
\hline D. ganjae & CBS 180.91 & Cannabis sativa & KC343112 & KC344080 & KC343838 \\
\hline D. helicis & AR 5211 & Hedera helix & KJ210538 & KJ420828 & KJ210559 \\
\hline \multicolumn{6}{|c|}{ (Continued on next page) } \\
\hline
\end{tabular}


control) using a 2-mm cork-borer. The plugs were inoculated into the wounds and sealed with Parafilm (Parafilm M, Bemis). Inoculated shoots were incubated in moist chambers (airtight plastic boxes: $29 \times 23.5 \times 5.5 \mathrm{~cm})$ in the dark. Each container had one inoculated shoot of each of the 18 treatments. Each treatment was replicated 5 times, and the entire experiment was repeated once. After 5 weeks, shoots were split longitudinally, the internal lesion length was measured, and small pieces of wood tissue $(1 \times 2 \mathrm{~mm})$ were plated out onto PDA media as above to confirm colonization by the inoculated isolates. The results were statistically analyzed in SAS (version 9. 2) using analysis of variance (ANOVA) to determine the least significant differences. Percentage of fungal reisolation was also determined.

Designing of PCR based species-specific primers. Speciesspecific PCR primers were designed for $D$. ampelina, $D$. foeniculina, and $D$. ambigua. These species together with $D$. novem were the most abundant; however, the pathogenic status of $D$. novem on grapevines was unknown; therefore primers were not designed for this species. All the primers were designed using Primer3 (https://sourceforge.net/ projects/primer3) in Geneious R8.0.5. The primers were designed to anneal to unique regions of the $t u b 2$ sequence for each target species.

Table 1. (Continued from previous page)

\begin{tabular}{|c|c|c|c|c|c|}
\hline Species & Strain/ isolate & Host & ITS accession & $t u b 2$ accession & EF1- $\alpha$ accession \\
\hline D. hickoriae & CBS 145.26 & Carya glabra & KC343118 & KC344086 & KC343844 \\
\hline D. impulsa & CBS 141.27 & Sorbus americana & KC343122 & KC344090 & KC343848 \\
\hline D. inconspicua & CBS 133813 & Maytenus ilicifolia & KC 343123 & KC344091 & KC343849 \\
\hline D. infecunda & CBS 133812 & Schinus terebinthifolius & KC343126 & KC344094 & KC343852 \\
\hline D. longicolla & CGMCC3.17089 & Glycine max & KF576267 & KF576291 & KF576242 \\
\hline D. longicolla & HM 347711 & - & KF576268 & KF576292 & \\
\hline D. longispora & CBS 194.36 & Ribes sp. & KC343135 & KC344103 & KC343861 \\
\hline D. lusitanicae & CBS 123212 & Foeniculum vulgare & KC343136 & KC344104 & KC343862 \\
\hline D. manihotia & CBS 505.76 & Manihot utilizsima & KC343138 & KC344106 & KC343864 \\
\hline D. nebulae & Phom 240 & Vitis sp. (rootstock) & KY511315 & KY511346 & MH708543 \\
\hline D. nebulae & PMM 1678 & Vitis vinifera & KY511334 & KY511366 & - \\
\hline D. nebulae & PMM 1681 & Vitis vinifera & KY511337 & KY511369 & MH708552 \\
\hline D. neilliae & CBS 14427 & Spiraea sp. & KC343144 & KC344112 & KC343870 \\
\hline D. cf. nobilis & CBS 113470 & Castanea sativa & KC343146 & KC344114 & KC343872 \\
\hline D. cf. nobilis & CBS 200.39 & Laurus nobilis & KC 343151 & KC344119 & KC344119 \\
\hline D. cf. nobilis & CBS 116954 & Pyrus pyrifolia & KC343148 & KC344116 & KC343874 \\
\hline D. cf. nobilis & CBS 116953 & Pyrus pyrifolia & KC343147 & KC344115 & KC343873 \\
\hline D. cf. nobilis & CBS 338.89 & Hedera helix & KC 343152 & KC 344120 & KC 343878 \\
\hline D. cf. nobilis & CBS 587.79 & Pinus pantepella & KC343153 & KC344121 & KC343879 \\
\hline D. novem & DPO 378 & Glycine $\max$ & KC343157 & KC344125 & KC343883 \\
\hline D. novem & CBS 127270 & Glycine $\max$ & KC343156 & KC344124 & KC343882 \\
\hline D. novem & Phom 201 & Vitis champinii & KY511307 & KY511340 & MH708550 \\
\hline D. novem & Phom 232 & Vitis sp. (rootstock) & KY511314 & KY511345 & MH708544 \\
\hline D. novem & Phom 257 & Vitis sp. (rootstock) & KY511319 & KY511351 & - \\
\hline D. novem & Phom 264 & Vitis sp. (rootstock) & KY511320 & KY511352 & - \\
\hline D. novem & Phom 290 & Vitis sp. (rootstock) & KY511323 & KY511355 & - \\
\hline D. novem & Phom 297 & Vitis sp. (rootstock) & KY511325 & KY511357 & - \\
\hline D. oncostoma & CBS 100454 & Robinia pseudoacacia & KC343160 & KC343402 & KC343886 \\
\hline D. oncostoma & CBS 589.78 & Robinia pseudoacacia & KC343162 & KC344130 & KC343888 \\
\hline D. ovoicicola & CGMCC 3.17092 & Lithocarpus glabra & Kf576264 & Kf576288 & KF576239 \\
\hline D. phaseolorum & CBS 116019 & Caperonia palustris & KC343175 & KC344143 & KC343901 \\
\hline D. pustulata & CBS 109742 & Acer pseudoplatanus & KC343185 & KC344153 & KC343911 \\
\hline D. pterocarpi & MFLUCC. 10571 & Pterocarpus indicus & JQ619899 & $\mathrm{JX} 275460$ & JX275416 \\
\hline D. rudis & AR 3422 & Laburnum anagyroides & KC843090 & KC843254 & KC843090 \\
\hline D. rudis & P86g1 & Vitis vinifera & AY485750 & JX2754554 & - \\
\hline D. serafiniae & BRIP 55665 & Helianthus annиus & KJ197274 & KJ197254 & KJ197236 \\
\hline D. serafiniae & Phom 225 & Vitis sp. (rootstock) & KY511313 & KY511344 & MH708545 \\
\hline D. serafiniae & Phom 242 & Vitis sp. (rootstock) & KY511316 & KY511347 & - \\
\hline D. serafiniae & Phom 247 & Vitis sp. (rootstock) & KY511317 & KY511348 & - \\
\hline D. serafiniae & Phom 249 & Vitis sp. (rootstock) & KY511318 & KY511349 & - \\
\hline D. serafiniae & Phom 255 & Vitis sp. (rootstock) & - & KY511350 & - \\
\hline D. subclavata & ZJUD 83 & C. grandis shatianyou & KJ490618 & KJ490439 & KJ490497 \\
\hline D. vaccinii & CBS 160.32 & Vaccinium macrocarpon & KC343228 & KC344196 & KC343954 \\
\hline D. vaccinii & DF 5032 & Vaccinium corymbosum & AF317570 & KC843225 & JQ807380 \\
\hline Phomopsis sp. 1 & STEU 5573 & Vitis vinifera & AY485724 & - & - \\
\hline Phomopsis sp. 2 & STEU 2674 & Vitis vinifera & AF230761 & - & - \\
\hline Phomopsis sp. 3 & STEU 4407 & Vitis vinifera & AY485725 & - & - \\
\hline Phomopsis sp. 4 & STEU 5464 & Vitis vinifera & AY485726 & - & - \\
\hline Phomopsis sp. 5 & STEU 5346 & Vitis vinifera & AY485728 & - & - \\
\hline Phomopsis sp. 5 & PMM 1657 & Vitis vinifera & KY511331 & KY511363 & - \\
\hline Phomopsis sp. 5 & PMM 1660 & Vitis vinifera & KY511333 & KY511365 & - \\
\hline Phomopsis sp. 6 & STEU 5135 & Vitis vinifera & AY485735 & - & - \\
\hline Phomopsis sp. 7 & STEU 5495 & Vitis vinifera & AY485742 & - & - \\
\hline Phomopsis sp. 8 & STEU 5462 & Vitis vinifera & AY485743 & - & - \\
\hline
\end{tabular}




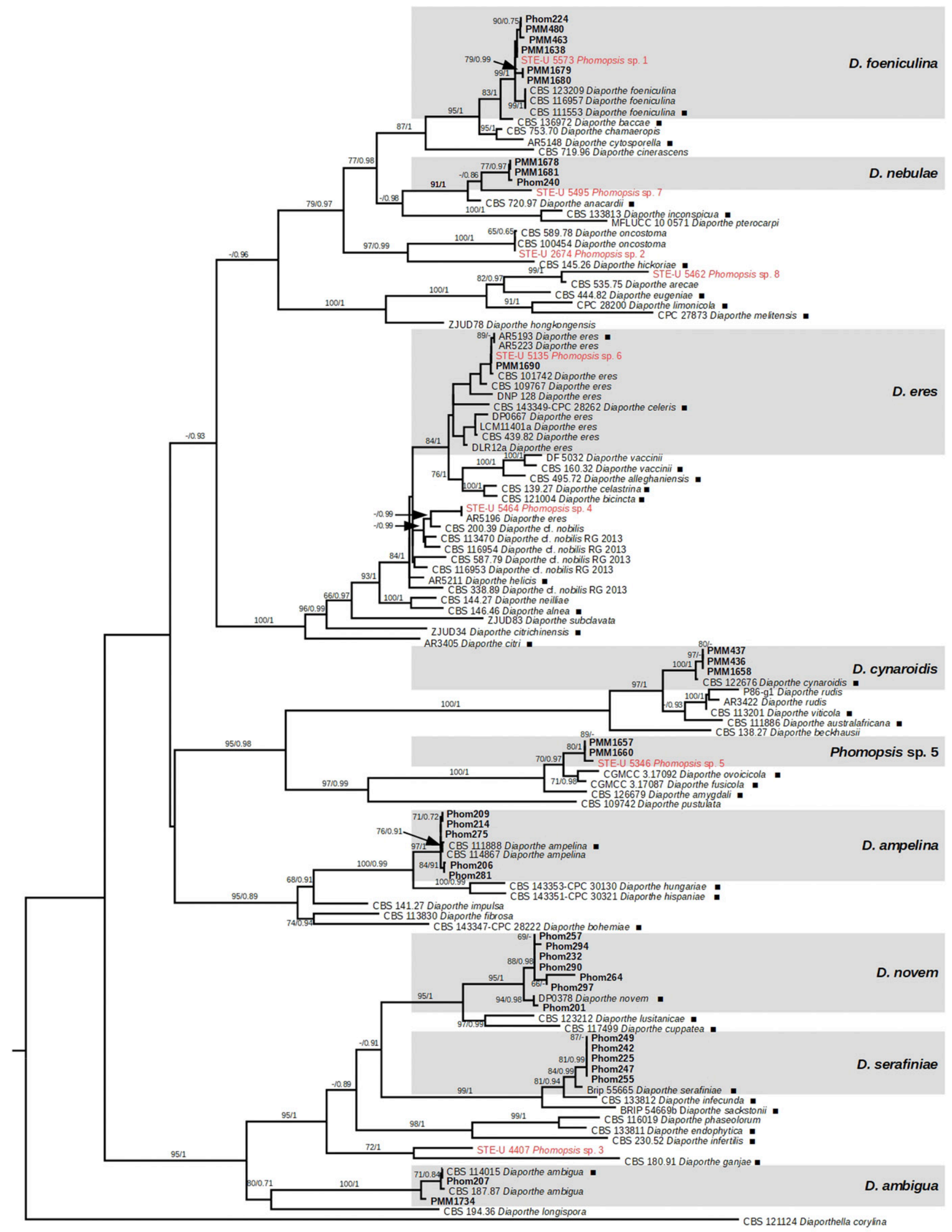

0.2

Fig. 1. Maximum likelihood phylogenetic tree of Diaporthe spp. based on combined ITS-tub2-EF1- $\alpha$ sequence data. Bootstrap support values $\geq 65 \%$ (calculated from 1,000 replicates) and Bayesian posterior probabilities $\geq 0.70$ are shown. The scale bar shows the number of substitutions per site. Species identified in the current study are in bold, and the clades are highlighted. Van Niekerk et al. (2005) isolates all begin with STE-U. Ex-type and ex-epitype isolates are indicated with a square. Diaporthella corylina used as outgroup. 
Two forward primers and two reverse primers were designed for each species. The primers were selected that had low hairpin and/or selfdimer stability, G/C content of 30 to $80 \%$, and melting temperature of $\sim 60^{\circ} \mathrm{C}$. Different combinations of primer pairs were evaluated for specificity, and eventually one species-specific set was selected per species. The species-specific primer sets designed and selected for each species are listed in Table 2 . The optimal annealing temperatures of the primers were determined by performing a gradient PCR with annealing temperatures varying from 55 to $65^{\circ} \mathrm{C}$. PCR reactions were performed in $10-\mu l$ reactions containing $1 \mu l$ of template DNA, $0.08 \mu \mathrm{M}$ of each primer, and $1 \times$ Kapa Taq ReadyMix PCR master mix. The standardized amplification regime for the primers was initial denaturation at $94^{\circ} \mathrm{C}$ for $5 \mathrm{~min}$ followed by 30 cycles of $30 \mathrm{~s}$ at $94^{\circ} \mathrm{C}, 30 \mathrm{~s}$ of annealing at $63^{\circ} \mathrm{C}$, and $30 \mathrm{~s}$ at $72^{\circ} \mathrm{C}$, and a final extension step at $72^{\circ} \mathrm{C}$ for $5 \mathrm{~min}$. In order to validate the primers, the specificity of the primer pairs was tested against 14 other Diaporthe spp. and species of other fungi often associated with grapevines, such as Phaeoacremonium minimum (FH-P 576), Diplodia seriata (FH-B 594), Eutypa lata (PMM 1756), Ilyonectria liriodendri (FH-C 695), Cadophora luteo-olivacea (FH-Cad 500), Cryptovalsa ampelina (PMM 1761), Fusarium solani (FH-Fus 5), and Basidiomycetes, i.e., Fomitiporia capensis (FH 136) and Phellinus resupinatus (FH 195). The PCR products were separated and visualized as above mentioned but using a $1.5 \%(\mathrm{wt} / \mathrm{vol})$ agarose gel. DNA for some recently described Diaporthe species closely related to the target species were not available for specificity testing, e.g., $D$. baccae (related to $D$. foeniculina), D. hispaniae, and D. hungariae (both related to D. ampelina). For these species, direct sequence comparisons were made to investigate the potential for species-specific primers to also amplify these species.

\section{Results}

Sample collection and fungal isolation. Diaporthe isolates were recovered from all three grapevine material types sampled. A total of 140 Diaporthe isolates were identified, 38 isolates were obtained from dormant rootstock propagation material, 40 from dormant grafted nursery vines, and 62 from dying or dead spurs. Isolates were obtained from black and brown streaking, V-shaped necrosis, as well as brown internal necrosis.

Phylogenetic analysis. The combined maximum likelihood tree (ITS, tub2, and EF1- $\alpha$ ) revealed nine clades containing Diaporthe isolates recovered from South African grapevines during this study (Fig. 1). The first clade (99\% bootstrap support, 1.00 posterior probability) consisted of six grapevine isolates which grouped together with $D$. foeniculina ex-type (CBS 111553) and two other isolates identified as D. foeniculina (CBS 116957 and CBS 123209) and Phomopsis sp. 1 (STE-U 5573). The second clade (77\% bootstrap support, 0.97 posterior probability) contained three grapevine isolates representing a unique and previously unsequenced species of Diaporthe (D. nebulae) which is closely related to $D$. anacardii and an unidentified species previously recovered from grapevines in South Africa (Phomopsis sp. 7). The third clade contained one grapevine isolate that grouped with D. eres (AR 5223, AR 5193, CBS 101742, and CBS 109769) and Phomopsis sp. 6 isolate STEU 5135 with a bootstrap support of $<65 \%$ and posterior probability $<0.70$. The fourth clade $(100 \%$ bootstrap support, 1.00 posterior probability) consisted of three grapevine isolates that grouped together with Diaporthe cynaroidis ex-type (CBS 122676). The fifth clade consisted of two grapevine isolates which grouped with Phomopsis sp. 5 (STE-U 5346) with a bootstrap support of $80 \%$ and posterior probability of 1.00 . The sixth clade ( $97 \%$ bootstrap support, 1.00 posterior probability) contained five grapevine isolates that grouped together with D. ampelina isolate CBS 111888 (ex-type) and CBS 114867 . The seventh clade (95\% bootstrap support, 1.00 posterior probability) consisted of seven grapevine isolates that grouped with the ex-type of Diaporthe novem strain CBS 127270. The eighth clade ( $84 \%$ bootstrap support, 0.99 posterior probability) consisted of five grapevine isolates that grouped with $D$. serafiniae (BRIP 55665) ex-type. The ninth clade (100\% bootstrap support, 1.00 posterior probability) consisted of two isolates from grapevines that grouped with D. ambigua ex-type (CBS 114015). Of the remaining isolates of Van Niekerk et al. (2005), Phomopsis sp. 7 (STE-U 5495) was closely related to $D$. anacardii (CBS 720.97) and the new species found in the current study (D. nebulae). Phomopsis sp. 4 (STE-U 5646) grouped together with D. eres (AR5196), with a support value of $<65 \%$ and posterior probability $<0.70$. Phomopsis sp. 3 (STE-U 4407) was related to D. ganjae (CBS 180. 91) with a bootstrap support value of $72 \%$ and posterior probability of 1.00 . Phomopsis sp. 8 (STE-U 5462) grouped with D. arecae (CBS $535.75)$ with $99 \%$ bootstrap support and posterior probability of 1.00, and Phomopsis sp. 2 (STE-U 2674) grouped with D. oncostoma (CBS 100454 and CBS 589. 76) with a bootstrap support value of $100 \%$ and posterior probability of 1.00 .

Taxonomy. Diaporthe nebulae Lesuthu; L. Mostert; C.F.J. Spies; Moyo; and Halleen, sp. nov. - MycoBank MB820340; Figure 2.

Etymology. Latin, from nebula meaning cloud, named because of its cloudy cultural growth. Conidiomata on WA with pine needles pycnidial, black, abundant on pine needles, mostly solitary, some aggregate, up to $337 \mu \mathrm{m}$ diam, exuding creamy conidial droplets from the ostioles. Conidiophores, hyaline, smooth, branched, straight to curved, densely aggregated, 1-3 septate (14-) $22(-33) \times(1.5-) 2$ $(-3) \mu \mathrm{m}$. Conidiogenous cells, hyaline, subcylindrical, rarely tapering toward the apex (4-) $13(-20) \times(1-) 2(-3) \mu \mathrm{m}$. Alpha conidia, abundant, aseptate, hyaline, smooth, acutely rounded apex, tapering toward both endings, bi- or multiguttulate, wide, ranging from (7-) $16(-18) \times(3-) 5(-7) \mu \mathrm{m}$. Beta conidia, hyaline, smooth, slightly curved, some spindle-shaped, (10) $42(-60) \times(2-) 3(-4) \mu \mathrm{m}$. Gamma conidia, not observed.

Culture characteristics. Colony diameter was $70 \mathrm{~mm}$ after 14 days at $25^{\circ} \mathrm{C}$ on PDA, white to off-white on the surface, and white with yellow patches underneath.

Material examined. SOUTH AFRICA, Western Cape Province, Constantia, on wood of Vitis vinifera, 16 April 2014, P. Moyo, holotype PREM 62198 (dried culture of PMM 1681), ex-holotype CBS 142721 = STE-U 8525 = PMM 1681; Western Cape Province, Stellenbosch, on wood of Vitis vinifera, 18 April 2014, P. Moyo, STE-U 8526 = PMM 1678; Western Cape Province, Wellington, on rootstock cuttings (Vitis sp.), 20 June 2013, F. Halleen, STE-U $8527=$ Phom 240.

Notes. Morphological differences were observed when comparing the new species (D. nebulae) isolates with those of the published closely related species, D. anacardii (Gomes et al. 2013) and Phomopsis sp. 7 (Van Niekerk et al. 2005). D. nebulae produced wider alpha conidia, longer conidiophores, and conidiogenous cells (Fig. 2 ). This species is currently known only from the southern side of the Drakenstein Mountains of the Western Cape (Boland area).

Table 2. Species-specific primer pairs designed and used in this study for the detection and identification of Diaporthe ambigua, D. ampelina, and D. foeniculina

\begin{tabular}{llll}
\hline Primer name & \multicolumn{1}{c}{ Primer sequence } & Target species & Amplicon size \\
\hline Dambigua_F1 & 5'-GTCTACAACCGCGACACT-3' & D. ambigua & $350 \mathrm{bp}$ \\
Dambigua_R2 & 5'-GGAGGCCTGGGCGATAAATG-3' & D. ambigua & $350 \mathrm{bp}$ \\
Damp_F1 & 5'-GCGTCAGATTGCTAAYACCAACC-3' & D. ampelina & 500 bp \\
Damp_R2 & 5'-CGATAACGCATTAGCAAGGTTCG-3' & D. ampelina & $500 \mathrm{bp}$ \\
Dfoen_F1 & 5'-GTACGCACCTCCTATTCCCTGTC-3' & D. foeniculina & $500 \mathrm{bp}$ \\
Dfoen_R1 & 5'-CTGTAGATGGTAACAACGTGGCT-3' & D. foeniculina & 500 bp \\
\hline
\end{tabular}


Pathogenicity. The analysis of variance (ANOVA) for mean lesion lengths for the two pathogenicity experiments showed significant interaction; therefore the two experiments could not be combined. Individual isolates within the species performed differently in the two experiments, suggesting intraspecific variation in pathogenicity. In the first experiment, D. ampelina isolates (FHPhom 206, FH-Phom 209, and FH-Phom 214) formed the longest

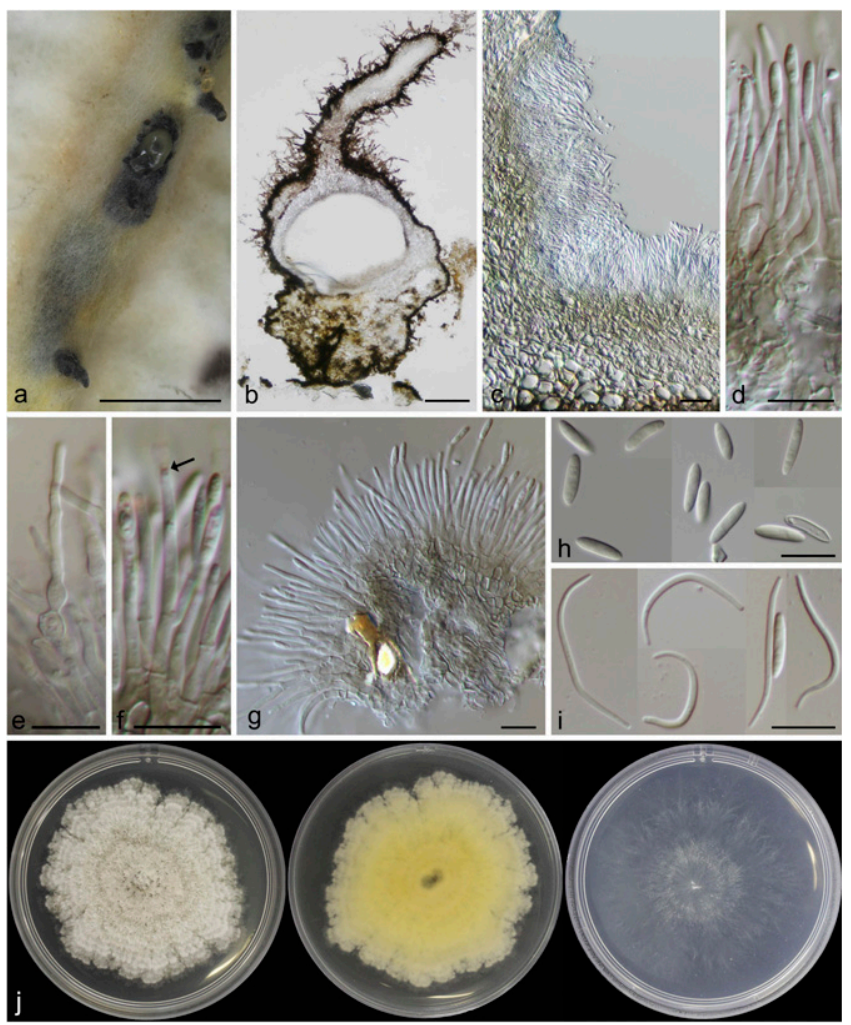

Fig. 2. Diaporthe nebulae (a) conidiomata sporulating on PDA, (b) longitudinal section through conidiomata, (c) section through coniomatal wall, (d, e, f, g) conidiophore and conidiogenous cells, (h) alpha conidia, (i) alpha and beta conidia, (j) front and back of 14-day-old culture on PDA and WA. Scale bars: $a=500 \mu \mathrm{m} ; b-c=100 \mu \mathrm{m} ; \mathrm{d}-\mathrm{i}=$ $10 \mu \mathrm{m}$. lesions (58.6-60.6 mm), followed by one isolate (PMM 1678) of D. nebulae $(44.8 \mathrm{~mm}$ ) (Table 3 ). However, the lesions formed by D. nebulae isolate PMM 1678 was not significantly shorter than lesions formed by the $D$. ampelina isolates. Isolates of $D$. cynaroidis (FH-Phom 436, FH-Phom 437, and PMM 1658) formed the shortest lesions $(4.8-15.7 \mathrm{~mm})$, which were not significantly different from the negative control. All the other isolates, D. novem (FH-Phom 201, FH-Phom 232, FH-Phom 257), D. serafiniae (FH-Phom 242, FH-Phom 249, FH-Phom 255), and D. nebulae (FH-Phom 240, PMM 1681) formed moderate lesions $(20.6-36.7 \mathrm{~mm})$ that were not significantly different from each other, but significantly longer than the negative control, and significantly shorter than those formed by the $D$. ampelina isolates. All the species were successfully reisolated from the shoots and were identified as being the same as the ones inoculated. The average percentage of reisolation was $79 \%$ for D. ampelina, $93 \%$ for D. novem, $97 \%$ for D. nebulae, $91 \%$ for D. serafiniae, $71 \%$ for D. cynaroidis. Diaporthe species were also recovered from $2 \%$ of the samples receiving the PDA negative control treatment (Table 3).

In the second experiment, D. ampelina isolates (FH-Phom 206, FH Phom 209, and FH-Phom 214) formed the longest lesions (48.8-65.6 mm). All D. cynaroidis isolates (FH-Phom 436, FHPhom 437, and PMM 1658) and two D. serafiniae isolates (FHPhom 242, FH-Phom 249) formed the shortest lesions $(2.3-12.6 \mathrm{~mm})$ that were not significantly different from the negative control. All the other isolates, D. novem (FH-Phom 201, FH-Phom 232, FH-Phom 257), D. nebulae (FH-Phom 240, PMM 1678, PMM 1681), and D. serafiniae (FH-Phom 255) formed moderate lesions (18.7-30.9 mm) which were not significantly different from one another, but significantly longer than the negative control and significantly shorter than those formed by the D. ampelina isolates. All the species were again successfully reisolated from the shoots and were identified as being the same as the ones inoculated in the second experiment. The average percentage of reisolation was $48 \%$ for D. ampelina, $48 \%$ for D. nebulae, $41 \%$ for D. serafiniae, $53 \%$ for D. cynaroidis, $57 \%$ for D. novem, and no Diaporthe species were isolated from the negative control (Table 3).

Designing of PCR-based species-specific primers. Speciesspecific primer sets were successfully designed for all three target species (D. ambigua, D. ampelina, and D. foeniculina). One primer pair per species was selected. These primer pairs amplified well at all temperatures tested. For $D$. foeniculina Dfoen_F2/Dfoen_R1, for $D$.

Table 3. Results from two in vitro pathogenicity experiments conducted with selected isolates of Diaporthe species and controls on detached Bukettraube shoots

\begin{tabular}{|c|c|c|c|c|}
\hline \multirow[b]{2}{*}{ Isolates } & \multicolumn{2}{|c|}{ Mean lesion lengths $(\mathbf{m m})^{\mathrm{y}}$} & \multicolumn{2}{|c|}{ Reisolation $(\%)^{\mathbf{z}}$} \\
\hline & Experiment 1 & $\overline{\text { Experiment } 2}$ & Experiment 1 & $\overline{\text { Experiment } 2}$ \\
\hline D. ampelina (FH-Phom 206) & $57.9 \mathrm{a}$ & $65.6 \mathrm{a}$ & 70.0 & 65.0 \\
\hline D. ampelina (FH-Phom 209) & $60.6 \mathrm{a}$ & $48.8 \mathrm{ab}$ & 67.5 & 20.0 \\
\hline D. ampelina (FH-Phom 214) & $58.6 \mathrm{a}$ & $56.4 \mathrm{ab}$ & 100.0 & 60.0 \\
\hline D. nebulae (FH-Phom 1678) & $44.8 \mathrm{ab}$ & 19.8 cde & 100.0 & 82.5 \\
\hline D. nebulae (FH-Phom 1681) & $36.7 \mathrm{bc}$ & $30.9 \mathrm{c}$ & 90.0 & 27.5 \\
\hline D. nebulae (FH-Phom 240) & 23.7 cde & $19.6 \mathrm{cde}$ & 100.0 & 35.0 \\
\hline D. novem (FH-Phom 201) & $31.6 \mathrm{bcd}$ & $31.5 \mathrm{c}$ & 92.5 & 52.5 \\
\hline D. novem (FH-Phom 232) & 26.9 cde & $32.6 \mathrm{c}$ & 90.0 & 50.0 \\
\hline D. novem (FH-Phom 257) & $30.6 \mathrm{bcd}$ & $24.0 \mathrm{~cd}$ & 95.0 & 67.5 \\
\hline D. serafiniae (FH-Phom 255) & 24.1 cde & 18.7 cde & 90.0 & 35.0 \\
\hline D. serafiniae (FH-Phom 249) & 21.4 cde & $12.6 \mathrm{def}$ & 92.5 & 42.5 \\
\hline D. serafiniae (FH-Phom 242) & $20.6 \mathrm{cdef}$ & $5.3 \mathrm{ef}$ & 90.0 & 45.5 \\
\hline D. cynaroidis (PMM 1658) & 15.7 defg & $9.5 \mathrm{def}$ & 65.0 & 62.5 \\
\hline D. cynaroidis (FH-Phom 436) & $12.7 \mathrm{efg}$ & $9.8 \mathrm{def}$ & 100.0 & 62.5 \\
\hline D. cynaroidis (FH-Phom 437) & $4.8 \mathrm{fg}$ & $2.3 \mathrm{f}$ & 47.5 & 32.5 \\
\hline PDA 1 & $0.0 \mathrm{~g}$ & $0.0 \mathrm{f}$ & 0.0 & 0.0 \\
\hline PDA 2 & $0.0 \mathrm{~g}$ & $0.0 \mathrm{f}$ & 6.7 & 0.0 \\
\hline PDA 3 & $0.0 \mathrm{~g}$ & $0.0 \mathrm{f}$ & 0.0 & 0.0 \\
\hline
\end{tabular}

${ }^{\mathrm{y}}$ Within each experiment, mean lesion lengths followed by the same letter were not significantly different. $\left(\mathrm{LSD}_{\exp 1}=16.23, \mathrm{P}_{\exp 1}<0.05\right)$, and $\left(\mathrm{LSD} \mathrm{exp}_{2}=15.3\right.$, $\mathrm{P}_{\exp 2<0.05)}$

${ }^{\mathrm{z}}$ Reisolation percentage was determined as the number of shoots from which the inoculated fungus was reisolated after a 5-week inoculation period. 
ampelina Damp_F1/ Damp_R2, and for D. ambigua Dambigua_F1/ Dambigua_R2 were selected. An annealing temperature of $63^{\circ} \mathrm{C}$ was chosen for all three selected primer combinations, as good amplification of the target species was observed at this temperature. Amplification was not seen in any of the nontarget Diaporthe species (Fig. 3) or fungi (results not shown). Sequence comparisons of the species-specific primers with available sequences of $D$. hispaniae (CBS 143351-CPC 30321) and D. hungariae (CBS 143353-CPC 30130 ) that are closely related to the target species $D$. ampelina indicates that the Damp_R2 primer does not match these species. Unfortunately, these GenBank accessions are not long enough to include the potential binding site for Damp_F1, so the specificity of this primer could not be confirmed. Unfortunately, the species-specific primers developed for $D$. foeniculina (Dfoen_F1 and Dfoen_R1) perfectly match the corresponding tub2 region of $D$. baccae (CBS 136972), which was described after the optimization of this assay.

\section{Discussion}

The primary aim of this study was to assess the status of Diaporthe species as dieback pathogens on grapevines in the Western Cape, South Africa. Previous Diaporthe species identified on South African vineyards were: $D$. ambigua, D. ampelina, D. amygdali, $D$. australafricana, D. helianthi, D. kyushuensis, D. rudis, and eight other isolates that were not identified to species level. D. ampelina and D. amygdali were found to be the most virulent (Mostert et al. 2001; Van Niekerk et al. 2005; White et al. 2011a). In the present study, Diaporthe isolates were obtained from dormant rootstock grafting material, dormant grafted nursery vines, and dying or dead spurs. A three gene (ITS, tub2, and EF1- $\alpha$ ) phylogenetic analysis revealed nine species of Diaporthe among these isolates: $D$. ampelina, D. ambigua, D. cynaroidis, D. eres, D. foeniculina, D. novem, D. serafiniae, Phomopsis sp. 5 (Van Niekerk et al. 2005), and a new species here described as $D$. nebulae that is related to $D$. anacardii. Of these, $D$. serafiniae and $D$. cynaroidis have not previously been reported from grapevines globally, and $D$. novem has not been reported from this host in South Africa. These first reports add to our knowledge of Diaporthe species on grapevines in South Africa.

The present study has also attempted to resolve the identity of isolates previously identified by Van Niekerk et al. (2005). Based on the phylogeny and morphological features, Phomopsis sp. 2 (STE-U 2674) grouped strongly with D. oncostoma (CBS 589. 78 and CBS 100456). The published morphological description of $D$. oncostoma (Gomes et al. 2013) is similar to that reported for Phomopsis sp. 2 by Mostert et al. (2001), confirming our phylogenetic identification of Phomopsis sp. 2 as D. oncostoma. Unfortunately, Phomopsis sp. 3 and 8 are only represented by ITS sequence data in the combined phylogeny. More strains and/or sequence data are needed to better resolve these species' identity. Phomopsis sp. 5 and Phomopsis sp. 7 occupied unique phylogenetic positions in the present study and could not be identified as currently known species. Phomopsis sp. 7 was closely related to, but distinct from, $D$. anacardii.

In our phylogeny, two species known from South African grapevines clustered in the Diaporthe eres species complex (Gomes et al. 2013; Lawrence et al. 2015; Udayanga et al. 2014b). Udayanga et al. (2014b) considered this species complex to be redundant and noted that the poorly supported nonmonophyletic grouping could be observed when ITS sequences are included in the combined analysis. They used seven gene areas to resolve the $D$. eres species complex and found CBS 587.79 and CBS113470, together with other isolates to cluster with $D$. eres when ITS is not included. Udayanga et al. (2014b) synonymized several species with D. eres. Technically, this clade should be referred to as D. eres, but it is not congruent with our phylogeny, e.g., Udayanga et al. (2014b) excludes D. vaccinii from $D$. eres, but includes $D$. cf. nobilis strains CBS 587.79 and CBS 113470, while in our phylogeny this concept of D. eres is polyphyletic. Our phylogeny concurs more with Lawrence et al. (2015), but this is to be expected in light of our use of the ITS region, and also the lack of CAL and HIS regions. Furthermore, neither Lawrence et al. (2015) nor Udayanga et al. (2014b) included the full set of D. cf. nobilis isolates as treated by Gomes et al. (2013) and as included here. The mean average of alpha conidia of PMM 1690 were $(6-) 7-9(-10) \times 2-2.5(-3) \mu \mathrm{m}$, which is very similar to those of the isolate Phomopsis sp. 6, (6-)7-9(-10) $\times 2-2.5 \mu \mathrm{m}$, and $D$. eres (6-)6.5-8.5(-9) × 3-4 $\mu \mathrm{m}$ (Van Niekerk et al. 2005; Udayanga et al. 2014b). The fact that PMM 1690 and Phomopsis sp. 6 (STE-U 5135) show high phylogenetic and morphological similarity to the exepitype strain of D. eres (AR5193 = CBS 1385594) confirms the identity of these strains as D. eres. Phomopsis sp. 4, however, clustered with $D$. eres strain AR5196 in one of two clades containing $D$. cf. nobilis isolates. Clearly, the taxonomy of the D. eres/nobilis clade needs further resolution before the species identity of Phomopsis sp. 4 can be elucidated.

The in vitro pathogenicity trials tested the ability of mycelium of selected Diaporthe species to infect wounded detached shoots of the cultivar Bukettraube and cause lesions. The interaction between the two experiments was most probably due to D. serafiniae isolates which caused larger lesions in the first experiment and were considered to be possible pathogens, whereas in the second experiment caused lesions that were not significantly different from the negative control and were considered as weak pathogens. The difference observed may also be due to differences in the lignin content of each individual shoot (Mutawila 2014), since lignin is involved in host resistance against colonization. Our pathogenicity trials suggest that $D$. cynaroidis is a nonpathogen of grapevines, but that $D$. novem, $D$. nebulae, and some isolates of $D$. serafiniae are pathogenic to this host. Lawrence et al. (2015) also found D. novem to be a pathogen of grapevines, D. cynaroidis is a pathogen of protea (Marincowitz et al. 2008), but our study was the first to test for pathogenicity on grapevine. Thompson et al. (2015) found $D$. serafiniae on sunflower but did not conduct pathogenicity studies on this host or any other host.

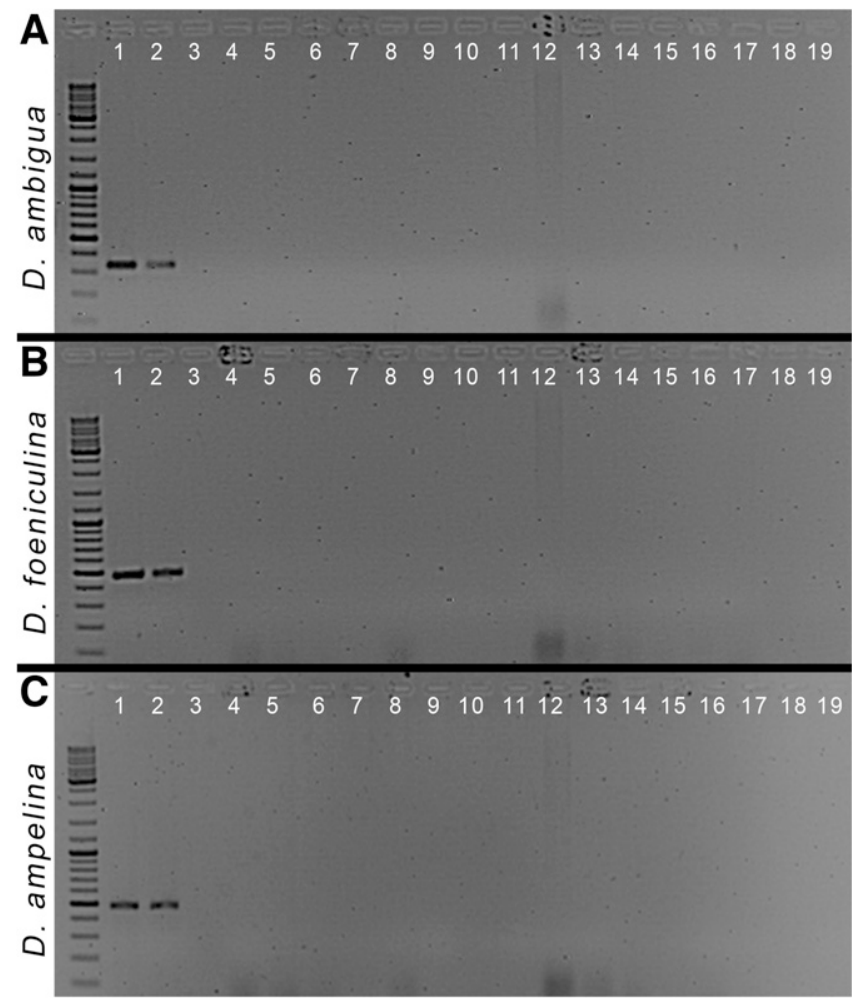

Fig. 3. Species-specific PCR amplification of (A) Diaporthe ambigua, (B) D. foeniculina, and (C) D. ampelina isolates. Lanes 1-2 contained product from the target organism. Lanes 3 and 18 were left open. Lanes 4-17 PCR amplification of all Diaporthe spp. identified during surveys of Western Cape vineyards and other alternative hosts planted close to vineyards: (4) $D$. novem, (5) D. serafiniae, (6) $D$. cynaroidis, (7) D. eres, (8) D. ambigua, (9) D. infecunda, (10) D. australafricana, (11) D. nebulae, (12) D. woodii, (13) Phomopsis sp. 7, (14) Phomopsis sp. 4, (15) Phomopsis sp. 8. Lanes 16 and 17 were the other two of the three species for which species-specific primers were designed. Lane 19 no template control. 
Studies have concluded that Diaporthe strains can only be identified to species level with the application of molecular techniques (Gomes et al. 2013; Guarnaccia and Crous 2017; Guarnaccia et al. 2018; Santos et al. 2017; Udayanga et al. 2014a, b). In the present study, a PCR-based assay was developed for the rapid and accurate identification of $D$. foeniculina, D. ampelina, and D. ambigua. However, these assays were not tested against some of their close relatives, i.e., D. baccae, D. chamaeropis, and D. cytosporella that are closely related to $D$. foeniculina; $D$. longispora that is closely related to $D$. ambigua; and D. fibrosa, D. hispaniae, and D. hungariae that are closely related to $D$. ampelina, because no material was available for such species. With the exception of D. baccae, data for these species show mismatches in the primer binding sites, which makes nonspecific amplification less likely. Unfortunately, the primer binding sites for the $D$. foeniculina primers perfectly match the corresponding region of $D$. baccae, suggesting that this species would also give a positive result. However, D. baccae was recently reported as a grapevine pathogen in Europe (Guarnaccia et al. 2018), suggesting that such a false positive would still be an indication of a grapevine pathogen. D. baccae has not been reported in South Africa. This is the first report of species-specific primers for D. ampelina, D. foeniculina, and D. ambigua.

This study identified nine Diaporthe species on grapevines in South Africa and clarified the taxonomic status of Phomopsis sp. 2 (Van Niekerk et al. 2005). This brings the total number of Diaporthe species known on this host in South Africa to 19. The focus of this survey (and that of Van Niekerk et al. 2005) was, however, on Diaporthe associated with grapevine wood, i.e., these species are more likely to be involved in Phomopsis dieback. To date, the only Diaporthe species affecting green shoots and leaves and causing Phomopsis cane and leaf spot in South Africa is D. ampelina (Mostert et al. 2001; Van Niekerk et al. 2005, 2011). Surveys of the species involved in Phomopsis cane and leaf spot are required to verify the Diaporthe species associated with this disease and provide a more comprehensive picture of the diversity of Diaporthe spp. on grapevines in South Africa.

\section{Acknowledgments}

We thank the Department of Plant Pathology, University of Stellenbosch for allowing the use of their facilities, Marieta Van Der Rijst for statistical analyses, ARC (Biometry Unit), Ihan Du Plessis for helping with preparing photo plates, and the ARC Infruitec-Nietvoorbij technical team for assistance (Carine Vermeulen, Julia Marais, Danie Marais, and Bongiwe Sokwaliwa).

\section{Literature Cited}

Baumgartner, K., Fujiyoshi, F., Travadon, R., Castlebury, L. A., Wilcox, W. F., and Rolshausen, P. E. 2013. Characterization of species of Diaporthe from wood cankers of grape in Eastern North American vineyards. Plant Dis. 97: 912-920.

Berrysmith, F. 1962. "Dead arm" disease of grapevines. N.Z. J. Agric. 105:309-313.

Carbone, I., and Kohn, L. M. 1999. A method for designing primer sets for the speciation studies in filamentous ascomycetes. Mycologia 91:553556

Damm, U., Mostert, L., Crous, P. W., and Fourie, P. H. 2008. Novel Phaeoacremonium species associated with necrotic wood of Prunus trees. Persoonia 20:87-102.

Darriba, D., Taboada, G. L., Doalla, R., and Posada, D. 2012. jModelTest 2: More models, new heuristics and parallel computing. Nat. Methods 9:772.

Díaz, G. A., Latorre, B. A., Lolas, M., Ferrada, E., Naranjo, P., and Zoffoli, J. P. 2017. Identification and characterization of Diaporthe ambigua, D. australafricana, D. novem, and D. rudis causing a postharvest fruit rot in kiwifruit. Plant Dis. 101:1402-1410.

Dissanayake, A. J., Liu, M., Zhang, W., Chen, Z., Udayanga, D., Chukeatirote, E., Li, X., Yan, J., and Hyde, K. D. 2015. Morphological and molecular characterisation of Diaporthe species associated with grapevine trunk disease in China. Fungal Biol. 119:283-294.

Du Plessis, S. J. 1938. The dead-arm disease in vine. Farming S. Afr. 2:79-83.

Farr, D. F., Castlebury, L. A., and Rossman, A. Y. 2017. Morphological and molecular characterisation of Phomopsis vaccinni and additional isolates of Phomopsis from blueberry and cranberry in eastern United States. Mycologia 94:494-504.

Fourie, P. H., and Halleen, F. 2004a. Occurrence of grapevine trunk disease pathogens in rootstock mother plants in South Africa. Australas. Plant Pathol. 33:313-315.

Fourie, P. H., and Halleen, F. 2004b. Proactive control of petri disease of grapevine through treatment of propagation material. Plant Dis. 88:1241-1245.
Girish, K., Bhat, S., and Raveesha, K. A. 2009. PCR-based detection of Phomopsis azadirachtae in die-back affected neem seeds. Arch. Phytopathol. Plant Prot. 42:626-632.

Glass, N. L., and Donaldson, G. C. 1995. Development of primer sets designed for use with the PCR to amplify conserved genes from filamentous ascomycetes. Appl. Environ. Microbiol. 61:1323-1330.

Gomes, R. R., Glienke, C., Videira, S. I. R., Lombard, L., Groenewald, J. Z., and Crous, P. W. 2013. Diaporthe: A genus of endophytic, saprobic and plant pathogenic fungi. Persoonia 31:1-41.

Guarnaccia, V., and Crous, P. W. 2017. Emerging citrus diseases in Europe caused by species of Diaporthe. IMA Fungus 8:317-334.

Guarnaccia, V., Groenewald, J. Z., Woodhall, J., Armengol, J., Cinelli, T., Eichmeier, A., Ezra, D., Fontaine, F., Gramaje, D., Gutierrez-Aguirregabiria, A., Kaliterna, J., Kiss, L., Luque, J., Mugnai, L., Naor, V., Raposo, R. Sandor, E., Vaczy, K. Z., and Crous, P. W. 2018. Diaporthe diversity and pathogenicity revealed from a broad survey of grapevine diseases in Europe. Persoonia 40:135-153.

Guarnaccia, V., Vitale, A., Cirvilleri, G., Alello, D., Susca, A., Epifani, F., Perrone, G., and Polizzi, G. 2016. Characterisation and pathogenicity of fungal species associated with branch cankers and stem-end rot of avocado in Italy. Eur. J. Plant Pathol. 146:963-976.

Guindon, S., Du-fayard, J. F., Lefort, V., Anisimova, M., Hordijk, W., and Gascuel, O. 2010. New algorithms and methods to estimate maximumlikelihood phylogenies: Assessing the performance of PhyML 3.0. Syst. Biol. 59:307-321.

Halleen, F., Crous, P. W., and Petrini, O. 2003. Fungi associated with healthy grapevine cutting in nurseries, with special reference to pathogens involved in the decline of young vines. Australas. Plant Pathol. 32:47-52.

Hawksworth, D. L. 2011. A new dawn for the naming of fungi: Impacts of decisions made in Melbourne in July 2011 on the future publication and regulation of fungal names. MycoKeys 1:7-20.

Hawksworth, D. L., Crous, P. W., Redhead, S. A., et al. 2011. The Amsterdam Declaration on fungal nomenclature. IMA Fungus 2:105-112.

Katoh, K., Asimenos, G., and Toh, H. 2009. Multiple alignment of DNA sequences with MAFFT. Methods Mol. Biol. 537:39-64.

Kearse, M., Moir, R., Wilson, A., Stones-Havas, S., Cheung, M., Sturrock, S., Buxton, S., Cooper, A., Markowitz, S., Duran, C., Thierer, T., Ashton, B., Mentjies, P., and Drummond, A. 2012. Geneious Basic: An integrated and extendable desktop software platform for the organization and analysis of sequence data. Bioinformatics 28:1647-1649.

Lartillot, N., Rodrigue, N., Stubbs, D., and Richer, J. 2013. PhyloBayes MPI Phylogenetic reconstruction with infinite mixtures of profiles in a parallel environment. Syst. Biol. 62:611-615.

Lawrence, P. D., Travadon, R., and Baumgartner, K. 2015. Diversity of Diaporthe species associated with wood cankers of fruit and nut crops in northern California. Mycologia 107:926-940.

Marincowitz, S., Crous, P. W., Groenewald, J. Z., and Wingfield, M. J. 2008 Microfungi occurring on Proteaceae in the fynbos. CBS Fungal Biodiversity Series 7:1-166

Moller, W. J., and Kasimatis, A. N. 1981. Further evidence that Eutypa armeniacae - not Phomopsis viticola - incites dead arm symptoms on grape. Plant Dis. 65:429-431.

Mostert, L., Crous, P. W., Kang, J., and Phillips, A. J. L. 2001. Species of Phomopsis and a Liberella sp. occurring on grapevines with specific reference to South Africa: Morphological, cultural, molecular and pathological characterization. Mycologia 93:146-167.

Moyo, P., Mostert, L., Bester, M., and Halleen, F. 2016. Trunk disease fungi associated with Diospryos kaki in South Africa. Plant Dis. 100:2383-2393.

Mutawila, C. 2014. Improving pruning wound protection against grapevine trunk disease pathogens. Ph.D. thesis. University of Stellenbosch, Stellenbosch, South Africa.

O’Donnell, K., and Cigelnik, E. 1997. Two different intragenomic rDNA ITS2 types within a monophyletic lineage of the fungus Fusarium are nonorthologous. Mol. Phylogenet. Evol. 7:103-116.

Pearson, R. C., and Goheen, C. 1994. Phomopsis cane and leaf spot. Pages 17-18 in: Compendium of Grape Diseases. W. B. Hewitt and R. C. Pearson, eds. American Phytopathological Society, St. Paul, MN, USA.

Prasad, M. N. N., Bhat, S. S., Raj, A. P. C., and Janardhana, G. R. 2006. Molecular detection of Phomopsis azadirachtae, the causative agent of dieback disease of neem by polymerase chain reaction. Curr. Sci. India 91:158-159.

Pscheidt, J. W., and Pearson, R. C. 1989. Effect of grapevine training systems and pruning practices on occurrence of Phomopsis cane and leaf spot. Plant Dis. 73: 825-828.

Rehner, S. A., and Uecker, F. A. 1994. Nuclear ribosomal internal transcribed spacer phylogeny and host diversity in the coelomycete Phomopsis. Can. J. Bot. 72:1666-1674.

Rossman, A. Y., Adams, G. C., Cannon, P. F., Castlebury, L. A., Crous, P. W., Gryzenhout, M., Jaklitsch, W. M., Mejia, L. C., Stoykov, D., Udayanga, D. Voglmayr, H., and Walker, D. M. 2015. Recommendations of generic names in Diaporthales competing for protection or use. IMA Fungus 6:145-154.

Santos, J. M., Correia, V. G., and Phillips, A. J. L. 2010. Primers for mating-type diagnosis in Diaporthe and Phomopsis: Their use in teleomorph induction in vitro and biological species definition. Fungal Biol. 114:255-270. 
Santos, J. M., and Phillips, A. J. L. 2009. Resolving the complex of Diaporthe (Phomopsis) species occurring on Foeniculum vulgare in Portugal. Fungal Divers. 34:111-125.

Santos, L., Alves, A., and Alves, R. 2017. Evaluating multi-locus phylogenies for species boundaries determination in the genus Diaporthe. PeerJ 5:e3120.

Thompson, S. M., Tan, Y. P., Shivas, R. G., Neate, S. M., Morin, L., Bissett, A., and Aitken, E. A. B. 2015. Green and brown bridges between weeds and crops reveal novel Diaporthe species in Australia. Persoonia 35:39-49.

Thompson, S. M., Tan, Y. P., Young, A. J., Neate, S. M., Aitken, E. A. B., and Shivas, R. G. 2011. Stem cankers on sunflower (Helianthus annuus) in Australia reveal a complex of pathogenic Diaporthe (Phomopsis) species. Persoonia 27:80-89.

Udayanga, D., Castlebury, L. A., and Rossman, A. Y. 2014a. Species limits in Diaporthe: Molecular re-assessment of D. citri, D. cytosporella, D. foeniculina and D. rudis. Persoonia 32:83-101.

Udayanga, D., Castlebury, L. A., Rossman, A. Y., Chukeatirote, E., and Hyde, K. D. 2014b. Insights into the genus Diaporthe: Phylogenetic species delimitation in the D. eres species complex. Fungal Divers. 67:203-229.

Udayanga, D., Liu, X., Crous, P. W., McKenzie, E. H. C., Chukeatirote, E., and Hyde, K. D. 2012. A multi-locus phylogenetic evaluation of Diaporthe (Phomopsis). Fungal Divers. 56:157-171.

Udayanga, D., Liu, X., McKenzie, E. H. C., Chukeatirote, E., Bahkali, A. H. A., and Hyde, K. D. 2011. The genus Phomopsis: Biology, applications, species concepts and names of common phytopathogens. Fungal Divers. 50:189-225.

Uecker, F. A. 1988. A world list of Phomopsis names with notes on nomenclature, morphology and biology. Mycol. Memoir 13:1-231.

Urbez-Torres, J. R., Peduto, F., Smith, R. J., and Gubler, W. D. 2013. Phomopsis dieback: A grapevine trunk disease caused by Phomopsis viticola in California. Plant Dis. 97:1571-1579.
Van Niekerk, J. M., Groenewald, J. Z., Farr, D. F., Fourie, P. H., Halleen, F., and Crous, P. W. 2005. Reassessment of Phomopsis species on grapevines. Australas. Plant Pathol. 34:27-39.

Van Niekerk, J. M., Halleen, F., and Fourie, P. H. 2011. Temporal susceptibility of grapevine pruning wounds to trunk pathogen infection in South African grapevines. Phytopathol. Mediterr. 50 (Suppl.): 139-150.

Vedashree, S., Sateesh, K. M., Chowdappa, P., and Nirmalkumar, B. J. 2015. Species-specific PCR-based assay for identification and detection of Phomopsis (Diaporthe) azadirachtae causing die-back disease in Azadirachta indica. J. Phytopathol. 163:818-828.

White, C. L., Halleen, F., Fischer, M., and Mostert, L. 2011b. Characterisation of fungi associated with esca diseased grapevines in South Africa. Phytopathol. Mediterr. 50:204-223

White, C. L., Halleen, F., and Mostert, L. 2011a. Symptoms and fungi associated with esca in South African vineyards. Phytopathol. Mediterr. 50:S236-S246.

White, T. J., Bruns, T., Lee, S., and Taylor, J. 1990. Amplification and direct sequencing of fungal ribosomal RNA genes for phylogenetics. Pages 315-322 in: PCR Protocols, A Guide to Methods and Applications. M. A. Innis, D. H. Gelfand, and J. J. Sninsky, eds. Academic Press Inc., New York.

Wilcox, W. A., Ellis, M. A., Rawnsley, B., Rossman, A., and Pscheidt, J. 2015 Phomopsis cane and leaf spot. Pages 68-71 in: Compendium of Grape Diseases, Disorders, and Pests, 2nd ed. W. F. Wilcox, W. D. Gubler, and J. K. Uyemoto, eds. American Phytopathological Society, St. Paul, MN, USA.

Zhang, A. W., Hartman, G. L., Riccioni, L., Chen, W. D., Ma, R. Z., and Pedersen, W. L. 1997. Using PCR to distinguish Diaporthe phaseolorum and Phomopsis longicolla from other soybean fungal pathogens and to detect them in soybean tissues. Plant Dis. 81:1143-1149. 